https://helda.helsinki.fi

\title{
Luther's Theology of Giving and the Gift
}

\section{Saarinen, Risto}

ATF Theology

2019

Saarinen , R 2019 , Luther's Theology of Giving and the Gift . in S Hultgren , S Pietsch \& J Silcock (eds) , Luther @500 and Beyond : Martin Luther's Theology Past, Present and Future . ATF Theology, Adelaide, pp. 143-166.

http://hdl.handle.net/10138/310401

unspecified

acceptedVersion

Downloaded from Helda, University of Helsinki institutional repository.

This is an electronic reprint of the original article.

This reprint may differ from the original in pagination and typographic detail.

Please cite the original version. 


\section{Luther's Theology of Giving and the Gift}

\section{Risto Saarinen}

In Lutheran theology, the gift is normally reviewed very positively. Salvation is God's gift. In his Catechisms, Luther speaks of God who gives all kinds of material and spiritual gifts to humans. As Luther is often critical of buying and selling, one would expect him to speak more positively about people who give gifts to other people. Often he does, but not always. Luther scholars are increasingly paying attention to the various differentiations Luther makes in speaking about gift-giving. In this paper, I give an overview of the current debates in this matter.

Giving and receiving are very ordinary phenomena, and one may wonder how they are relevant for theology in general and for Martin Luther in particular. I will therefore start my presentation with two introductory passages. First, I outline some biblical and early Christian dimensions of giving and the gift. Second, I look at the ongoing discussions on giving and the gift in humanities, especially sociology and anthropology. Luther scholars are increasingly paying attention to these discussions. After these two introductory passages, I will proceed to the different topics of Luther's theology.

\section{Biblical and Early Church Background}

The basic Greek verb "to give", didômi, occurs in the New Testament over 400 times, being one of its most frequent verbs. In addition to its concrete meanings, the verb often describes abstract divine and Trinitarian giving especially in the Johannine writings. God is directly called the giver 104 times in the New Testament, of which 42 are in John's Gospel and John's letters. In addition to these, the so-called divine passive of the type "he was given the power" (Rev. 6:4) often occurs as an indirect reference to divine giving. Jesus Christ is presented as giver 68 times, of which 26 are in John. Moreover, Jesus is portrayed as the recipient of what God gives 28 times in John.

Language scholars (e.g. Newman 1996) tend to regard "to give" as a basic verb which has similar semantics in many or even most languages. Without going too deep into difficult linguistic issues, we may assume that the European languages employ a standard and in some sense even universal semantic field of giving. The Hebrew background plays a role in some New Testament personal names, for instance, Matthew and Nathanael, which both allude to "God's gift".

The basic semantics of the verb "to give" as well as the noun "gift" presuppose a subject, that is, the giver, and two objects, namely, the gift which is given and the recipient who receives; giving thus exemplifies the so-called ditransitive action. Such action requires three places or 
so-called arguments, namely, the giver, the gift and the recipient. Moreover, the first and the third place must in normal cases be taken by living beings. Therefore, we say, for instance, "I give this book to you" but: "I put the book in the bookshelf". This very simple observation has already some theologically relevant dimensions, as the recipient of divine giving must be in some sense living and thus active. In Lutheran theology, we normally consider that the recipient of God's gifts remains passive. At the same time, however, this recipient cannot be like a stone or a bookshelf, since the recipient of the gift needs to be a living person. For instance, saying that baptism is a gift of God implies that dead or inanimate objects cannot be baptized, since a gift can only be given to living person. An infant who receives baptism remains in some sense totally passive, but he or she also needs to be alive in order to receive the gift of baptism properly. In this sense, passivity and living openness coincide in receiving a theological gift.

In biblical times, both Jews and Christians but also many other people living in the Mediterranean world regarded the whole universe around them as a gift of God. Sun, moon, rain, food, water, friends, and even all animals and plants were regarded as given by God. Human beings participate in the circle of giving and receiving in their everyday life. The Jewish background of this idea is prominent in Psalm 104, which says of God, for instance, that

you set the earth on its foundations ... you make springs gush forth in the valleys, ... you cause the grass to grow for the cattle, and plants for people to use, to bring forth food from the earth ... these all look to you, to give them their food in due season; you give to them, they gather it up, when you open your hand, they are filled with good things.

In this same spirit, the apostle Paul exclaims: "What do you have that you have not received!" (1 Cor 4:7b). Jews and early Christians considered living constantly as recipients of God's giving.

This prominent biblical and cultural idea was also employed by Stoic philosophers. Paul's contemporary, the Roman philosopher Seneca, describes the universe and human beings as follows in his De beneficiis (4,6-9):

God has built a huge residence for you, it holds no risk of fire or subsidence ... where did you get that breath which you draw? Or that light which enables you to arrange and order your actions? Or the blood which holds in the warmth of life with its circulation? Or those delicacies, which excite your palate with their rare flavors long after you, have eaten enough? ... These blessings, friend, a deity bestowed ... a deity it is that has sent out not just a few oxen, but whole herds of them through the entire world, who provided fodder for flocks everywhere as they roam in all directions ... God confers on us the greatest and most important favors without any thought of return.

In his Catechisms, Martin Luther speaks about God's gifts in a manner which is very similar to Psalm 104, Paul and Seneca. 
One particularly important and fascinating aspect of how important God's giving was considered in the early church can be seen in the Christian art. Let us make a small thought experiment in which we consider the different parts of human body and their symbolic role in various theological matters. The eyes are connected with faith and intellect, which give us a vision of God. The ears have been considered very important in Lutheran theology, because Luther so often considers that faith comes from hearing the word of God. He can even say that Christians primarily needs ears in the communication with God. The human heart is another body part that is prominent in the Bible and in Christian doctrine. The heart is considered as the seat of emotional life and so it in many ways contains the fruits of the Holy Spirit and the major Christian virtues such as joy and love and patience.

"Giving" is in many cultures and in the Bible connected with another body part, namely, the hands. The Psalm 104 says "when you open your hand, they are filled with good things". God's hands are considered as the vehicle, the instrument through which God gives good things. This is anthropomorphism, since humans also give to one another with their hands, so that hands symbolize giving in general. If we want to speak about God, or depict God's action by means of art, we inevitably use anthropomorphic pictures. Hands are a very good picture of giving since they exemplify the same thing as the verb "to give", namely, that the event of giving and receiving occurs between persons. This verb depicts an intentional action and not merely a natural or non-personal event or movement. Only persons have hands, while stones have not and animals have paws and other kinds of body members. Hands belong to persons. Hands thus symbolize a personal action, assuming both the giver's intention and the personal recipients.

When we look at early Christian art, we see that the face and the body of the Father are not normally pictured in an anthropomorphic fashion. The most common artistic symbol of Godfather is the hand of God, manus Dei, which is normally seen in the top of paintings and reliefs. Like in Psalm 104, it is often an open hand, stretched towards recipients in an act of giving and blessing. One of the earliest examples is the hand of God in the Jewish synagogue of Dura Europos ( $3^{\text {rd }}$ century). Early Christian examples include many mosaiques and the earliest portrayals of Mary and the child. A link between the Old and the New Covenant can also be made in such iconography. The hand of God gives the Decalogue to Moses, and the same hand then gives blessing to Christ, the apostles and the saints.

Today's thinkers reflect on the so-called theology of the body, highlighted by the late Pope John Paul II. Too often, this theology remains limited to the issues of sexuality. The human hand contains new symbolic resources of such reflection, as this body part depicts issues of giving and receiving, teaching and learning, status and submission. Our hands join us with God, and they distinguish us from most other creatures. 
Until the medieval times, the hand of God remains the most common symbol of the Father in Christian art. Especially in the medieval West, it then becomes more common to depict the Father anthropomorphically, with face, body, and limbs. Therefore, the hand of God as symbol lost some of its importance. However, even in fully anthropomorphic pictures the symbolic significance of the divine hand is often easy to see. The most famous example of this kind is provided by Luther's contemporary, Michelangelo. In his Sistine chapel paintings, Michelangelo emphasizes the hand of God in creation. Pointing out towards Adam, the hand of God creates a communicative relationship between God and humanity.

\section{Anthropological and Historical Considerations}

My second introductory point concerns current anthropological and sociological theories of gift and giving. For Christian theologians, such theories have a twofold significance. First, many new studies underline the importance of these theories for the understanding of early modern Europe. They thus belong to Luther's immediate historical surroundings. Second, there is a missionary or missiological significance. If these theories are universally valid and employed by nations and people all over the world, Christians should be aware of them to explain their relationship to money, gifts and other economic matters.

A hundred years ago, anthropologists started to discuss the division of labor in societies, which do not use money. They soon found out that the exchange of gifts, favors and services in archaic societies serves the same purposes which are fulfilled through buying and selling in contemporary societies. Giving gifts to one another makes you a member of a group and insures you for worse times. When in need of help, you can expect services from those people to whom you have given gifts earlier. Gifts in non-monetary societies are not merely free gifts or forms of charity. They constitute the societal status, the division of labor and social security, as Marcel Mauss argues in his classical anthropological study The Gift.

The next generation of anthropological and sociological discussion, prominent in the 1960s and 70s, considered that all gifts are, as a result of such necessary exchange, merely masked payments. "There is no free lunch", these scholars conclude, meaning that all gifts and favors can finally be reduced to the laws of market economy. Somebody needs to pay for all seemingly altruistic actions. According to this view, the gift is basically the same thing as payment with money.

Today, however, not very many sociologists defend this position. It has become more common to say that there are indeed such things as free lunches, and even genuine altruism is often possible. Many scholars (e.g. Godbout 1998, Zemon Davis 2002) assume that people give and receive by two basic models of circulation. There is, on the one hand, buying and selling, the rule of commerce, economy and bargaining. In such exchange, everything is counted according to value and merits, while altruism and gratitude do not play much role. 
On the other hand, there is the realm of free giving, in which you donate blood, give money to church collect or to the Red Cross, buy Christmas presents to your children and friends, help strangers and people in need.

Although counting your resources is also relevant in this second realm, and while the gifts circulate and may come back to you in due course, this second realm of free giving cannot be reduced to the laws of monetary economy. Such virtues as charity, gratitude, generosity, mercy and forgiveness belong to the realm of gift-giving in which persons are not evaluated by their resources and merits. Religious modes of giving and receiving often belong to this separate realm of gifts.

The circulation of gifts is, however, fairly complex, as current social philosophers (e.g. Henaff 2010) often make a distinction between three different modes of giving and receiving gifts. There is

a) a mode in which you do not pay attention to the recipient but try to give as freely and altruistically as possible. Giving money to the Red Cross or donating blood for the hospital are examples of this kind. In such giving, the recipient does not know your name and thus no bonds between the giver and the recipient emerge. Many biblical modes of giving are of this kind. We may recollect Jesus saying that your left hand should not know what your right hand gives, and that the Father lets rain come over all people alike. But there is also

b) another mode in which the exchange of gifts creates a bond between the giver and the recipient. Gifts of this kind are typically used in non-monetary societies, as when a farmer helps another farmer in harvest, expecting similar help in due season. Inviting your friends to lunch is often a gift of this kind, since at some point your friend will also invite you to lunch or maybe to a party. Anthropologists often call such gifts ceremonial, meaning that the most important thing is not the gift itself. What really matters is the act or the ceremony that creates friendship, hospitality and other important bonds of society.

c) A third mode of gift exchange is at stake when you inherit something, like family jewels or family furniture, or maybe a piece of land, or when you display the so-called filial piety to your parents and ancestors. This is mode is both very generous and a strictly limited gift exchange. Through such exchange, some material and often also immaterial treasures are moved from one generation to another. Sociologists call this mode "keeping-while-giving" (Weiner 1992), underlining the fact that the generous gift nevertheless stays within the family. This third mode has some important theological dimensions, especially through the Greek words paradidomi and paradosis, which in the New Testament mean handing over a valuable deposit or tradition. Doctrinal tradition in particular can be regarded as gift in this third sense. By means of tradition, the message of Christ is safeguarded by a community of insiders who are aware of the valuable nature of this truth. Such gifts are circulated in 
the line of succession in which the next generation receives the important gift from the previous generation.

Biblical scholars and Reformation historians have paid increasing attention to the circulation of different gifts. An obvious reason for the historical importance of gift circulation is that not all people used money in the Roman society or in early modern Europe. Farmers and other relatively poor people paid for the services by performing other services to one another in due course. The economy of lower classes thus resembled the anthropological observations collected from non-monetary societies.

Also rich people employed both (1) monetary economy and (2) the circulation of gifts. The codes of honor often demanded that noble services cannot be paid by money. Other instruments, like the display of loyalty and the habit of returning gifts were considered more adequate. Rich people in particular insisted on generosity and gratitude rather than monetary payments. Natalie Zemon Davis (2002) has demonstrated the importance of gifts in the Europe of Luther's times. She refers to the famous author and Luther' contemporary Francois Rabelais, who in his classical novel Gargantua and Pantagruel tells an anecdote of the warrior Grandgousier. This warrior had captured a fearful pirate king. Instead of demanding ransom and other payments from him, Grandgousier sends the pirate king back to his own homeland loaded with gifts. Grateful for this generosity, the pirate king later comes back to Grandgousier, offering him 9000 ships full of gold. However, Grandgousier refuses to accept any gold. The result is that the pirate king, overwhelmed by this continuing generosity, voluntarily subjects himself to Grandgousier and promises to pay him two million pieces of pure gold every year.

The moral of this fictional story of Rabelais is that true lords and masters do not rule by demanding payments. Instead, their sovereignty is based on gifts that circulate between the ruler and the subjects. The king should give everything freely to the subjects. As a result, gratitude can be expected, and it also becomes visible as voluntary gifts. One should not mistake such gift exchange for payments, since payments are for small-minded people in their petty businesses. The greatest things are not sold and bought. They are exchanged freely as gifts. Obviously, the reality was not so elegant as this ideal. It is nevertheless important that the people of the $16^{\text {th }}$ century were very well aware of how money and bargaining works on the one hand and how gifts and gratitude work differently on the other hand. Natalie Zemon Davis calls these two cultural modes the gift mode and the sales mode. She investigates carefully the use of each mode in different societal interactions. Regarding religion, the claims that

the religious reformations of the sixteenth century were a quarrel about the gifts, that is, about whether humans can reciprocate to God, about whether humans can put God under obligation, and about what this means for what people should give to each other. 
The religious quarrel stands on its own and is argued in its own terms, but is parallel to the quarrel about the king's obligations to his subjects. (Zemon Davis 2002, 167-68).

This very insightful quote allows us to move from the introductory passages to my actual topic, Luther's Theology of Giving and the Gift. In the following, I visit various themes of Luther's theology very briefly, pointing out some recent scholarship. My aim is to show in which ways the ideas of gift-giving and reciprocity are relevant for different classical Lutheran doctrines. As my visits remain brief, they are no exhaustive treatments of the topic but merely sketches pointing towards new issues and perspectives available in today's Luther research.

\section{Luther's Theology of the Gift}

Martin Seils (1985) claims programmatically that Luther's theology proceeds in terms of giving. The feature of giving is particularly visible in the explanation of the Creed in the Catechisms. There Luther depicts God's action in terms of giving and self-giving. The Large Catechism explains the first article of the Creed as follows:

What is meant by these words or what do you mean when you say, I believe in God, the Father almighty, creator etc. Answer: I hold and believe that ... He has given me and constantly sustains my body, soul, and life, my members great and small, all my senses, my reason and understanding, and the like; my food and drink, clothing, nourishment, spouse and children, servants, house and farm, etc. Besides, he makes all creation help provide the benefits and necessities of life - sun, moon, and stars in the heavens; day and night; air, fire, water, the earth and all that it yields and brings forth; birds, fish, animals, grain, and all sorts of produce. Moreover, he gives all physical and temporal blessings good government, peace, security. Thus we learn from this article that none of us has life ... from ourselves.

Luther's explanation of the second article of the Creed goes even further in claiming that God has also given himself completely to us in Christ. The Catechisms continue the intellectual history of Psalm 104, Seneca and Paul in claiming that all our everyday things, from food and clothing to sun and moon, are given by God. In some sense, everything is a gift. We only have what we have received from others (1. Cor. 4:7), in particular God..

Seils (2009) emphasizes that Luther's theology joins with such anthropological visions that do not reduce all free giving and gifts to buying and selling. Instead, Luther regards gift exchange to be different from monetary economy. Therefore, Luther's significance in the broader Western philosophical and cultural discussion consists in his emphasis of God's giving as the paradigm of disinterested, free gift. Lutheran theology aims at defining and making explicit the free gift of God, considering it to be different from the economy of buying and selling. In his exposition of central biblical passages Luther underlines the 
unconditional and free nature of God's gifts. Luther often employs a double wording, "gabe und geschenk", that is "gift and present". The word geschenk, present, underlines the concrete nature of divine giving and in particular the self-giving of Christ in the act of salvation. In this sense, a theological "present" does not require any human contribution. It comes from God alone and is a divine reality (Seils 2009, 104).

Luther's Catechisms receive and reformulate the biblical background of divine giving and self-giving. The mode of self-giving presupposes that God in Christ is both the giver and the gift. Some of the classical exegetical and theological problems are connected with the issue to whom this gift is given. When John 3:16 says famously that God "gave his only Son" so that the believers may have eternal life, it is not stated clearly who is the recipient of this selfgiving. In some sense it may be the world or the believers who benefit from this gift. In terms of Anselm's soteriology, however, the Son is given back to Father, and Anselm opposes the view that the Son would be given as ransom to the devil. When Luther scholars investigate the matter of divine giving, they may reach better understanding of these important matters of soteriology and atonement.

To grasp this rich theological complexity, Oswald Bayer considers Luther's theology in terms of so-called "categorical gift". This expression is a modification of Immanuel Kant's "categorical imperative", saying that the basic ethical command of treating others well is unconditional and absolute. Bayer wants to say that God does not require any preconditions from humans. God's gift is unconditional and absolute and in this sense "categorical". God does not relate to us in terms of merits or "sales mode", but with unconditional or categorical generosity. God is like the king who does not rule with a demand for payments. God rules with the unconditional outpouring of gifts, in the "gift mode" instead of "sales mode".

Lutheran theology, both historically and systematically, is shaped in the controversy between payments and sales on the one hand, and generosity and gift on the other. While sociologists may claim that there is no free lunch or free gift, Lutherans consider that the biblical God exercises a model of free giving, which is different from monetary economy. God's free giving incites Christians to practice free giving in their neighborly love. Some historical controversies of the Reformation can be elucidated by distinguishing between the sales mode and the gift mode. This work sometimes also brings forth surprising and controversial results. Let us next apply the insights of gift discourse to some prominent issues of Luther's theology.

\section{Indulgences}

For Protestants, the controversy regarding indulgences is the classical example of how God does not demand payments and how we cannot buy upgrading to our future life. This is 
because God does not rule in the sales mode, but in the gift mode, like the generous king. Most Luther scholars agree with this standard interpretation of indulgences.

However, there is more to be said about the indulgences. In his new study (2016), Berndt Hamm presents a highly provocative claim that Luther was not merely criticizing papal indulgences but also continuing the medieval theology of indulgences in his own way. In some sense, Luther even recommends the same kind of treasure of grace that was considered to be available in indulgences. How is this possible?

Hamm argues that the late medieval and Reformation period was characterized by the socalled nahe Gnade, near grace or proximity of grace. In their eschatological expectation, late medieval Christians were afraid of the last judgement. At the same time, they also believed that God's grace was available in new ways before the end of the world. Earlier, in the days of Augustine and Anselm of Canterbury, the work of Christ was good enough to bring a just satisfaction and adequate payment for the guilt and penalties of sinful humankind. From the late $13^{\text {th }}$ century onward, however, people increasingly started to believe that God's grace is abundant and can cover much more than what is minimally required to overcome evil powers.

Indulgences were an ecclesiastical means to regulate this abundant grace. As the cumulation of grace became bigger during the Renaissance and the Reformation, indulgences could also cover much more penalties than in earlier times. The presence of abundant grace was a joyful message, a gospel preacher by those who were selling or otherwise offering indulgences. Hamm points out that most indulgences were not bought with money but were offered as reward for pilgrimage and works of charity.

When Luther says in his 95 theses that the true treasure of the church is the gospel in Jesus Christ, he is on the one hand criticizing the problematic economic practices manifested in indulgences. On the other hand, he also participates in the big current of nahe Gnade, the proximity and abundance of grace. In some sense, he is making the maximum offer. God's grace is so abundant that it can cover for the guilt and penalty of humankind sola gratia, by itself and without additional efforts or payments. In this sense, there is not only opposition to indulgences in Luther but also a coherence and continuation of the late medieval theology of grace.

The history is complex and I will simplify it through presenting two illustrations which are my own rather than Hamm's. The first illustration says that this development is like a transformation from the sales mode towards the gift mode. In the times of Anselm, God's salvific action was considered in terms of satisfaction and redemption, a sort of payment in which the real price is paid. When the amount of grace increases, the role of payment becomes more complex. On the one hand, salvation is more from grace than before. On the 
other hand, payments, merits and achievements have new religious significance. Indulgences belong to this mixed economy of gifts and payments. Such mixed economy is typical in the non-religious life of the sixteenth century, as we can read from Natalie Zemon Davis's study. Berndt Hamm remarks that indulgences were not considered payments in the modern sense, as they did not work automatically but assumed the mixed economy of interpersonal giftgiving and charity. Luther's preaching from grace alone is the final step to religious gift economy. As no payments are needed, religious life is distinguished from the worldly realm of buying and selling. This first illustration can be argued from the historical sources with precision.

The second illustration is anachronistic and pedagogical rather than scholarly. Let us imagine a cloud of all knowledge. Humans can learn some of it through hard work but they cannot download this knowledge directly from the cloud. Then, a device is invented which can access this cloud and download knowledge if you make a small payment. This first phase is like the invention of historical indulgences. You may save some trouble through making a payment and obtain a very limited access to some resource. In the next step, you can have a monthly payment against which you can access either a certain amount of knowledge from the cloud or even an unlimited amount if your monthly payment is big enough. This second step corresponds to the late medieval and Reformation practices of papal indulgence, in which you can avoid some of the penalties or even most past and future penalties by means of payment or other agreement with the one providing this service.

In the final step of this anachronistic illustration, someone comes and says that all people can have a free and wireless access to this cloud of knowledge. You do not need monthly payments or any special agreement with the service provider. It is enough to connect one's own device to this resource without using third parties or monetary payments. This third phase resembles Luther's preaching that Christ alone and grace alone are sufficient for our salvation. In this end time, we realize that the abundant grace is available for free, gratis. While my anachronistic illustration has its own flaws and problems, it manifests some aspects of Hamm's claim that Luther was both fighting against indulgences and following the theology of abundant grace behind them. When we understand the differences and overlappings between the sales mode and the gift mode, we can also grasp the meaning of indulgences in a new manner.

\section{Theology of the Cross}

Bo Holm (2006) has interpreted the development of young Luther in terms of gift exchange and reciprocity. The young monk Luther wanted to purify the Christian's relationship to God of all reciprocity and human involvement. To accomplish this, Luther pleads for an extreme humility in which the person must renounce himself or herself completely. By means of this extreme renunciation the Christian lets God be God, affirming divine monergy in salvation. 
At some point (maybe around 1518) Luther realizes, however, that such an extreme renunciation is, paradoxically, just another form of self-righteousness. When the humble person "nails himself to the cross so high that his feet no longer touch the ground", as Luther puts it, the person in fact elevates himself rather than practices a truthful theology of the cross. When Luther realizes that he can only renounce himself up to a certain point and not beyond that point, he can leave exaggerated humility behind him and begin to trust in God. Due to this new trust, he can affirm the world and maybe even himself in some sense. The mature Luther thus replaces exaggerated humility with a confidence in God and a more positive view of human reception. This view may even contain some co-operation in positively receiving the gift given rather than renouncing everything.

To put the matter in systematic terms: you can only renounce yourself and sacrifice yourself up to a certain point in Christianity. After that point, you need to renounce you renunciation and sacrifice your sacrifices, so that you come beyond self-righteousness. This final point allows you in some sense to affirm the world and yourself in a new manner.

These results of Bo Holm resemble the work of Canadian philosopher Charles Taylor who in several works (e.g. 2002) argues that the Protestant Reformation achieved a new appreciation of ordinary life. Taylor considers that there is a difference between Greek philosophy and Christianity in the matter of renunciation. While Socrates and the Stoics claimed that they do not lose anything in renouncing the world, Christians have always experienced that, in renouncing the world, they really lose something of God's good creation. Thus, Christian renunciation is an affirmation of the goodness of what is renounced. Renunciation and ascetism are, therefore, ambivalent phenomena that may lead to a real loss of the good life. In Taylor's view, the Protestant reformers are very adequately aware of this ambivalence. (Saarinen 2009, 27).

Given this, the best way to affirm God's omnipotence and monergy does not consist in an exaggerated humility. Instead, Christians are called to affirm the goodness of God's creation and be grateful. Christians do not remain merely passive but they circulate God's good gifts. Bo Holm considers that the mature Luther in this manner approaches the anthropological theories of reciprocity to some extent. While most scholars today agree that Luther turns away from exaggerated humility in his mature years, Bo Holm's claim of anthropological reciprocity in Luther has created much debate. This has led to new studies on the theological significance of neighbourly love in Luther.

\section{Neighbourly Love}

Bo Holm claims that Christians in their neighborly love and service to God give themselves to this service. In this manner, the self-giving of Christ is continued in the self-giving mode of neighborly love. The Finnish scholar Antti Raunio argues in a similar manner on the basis 
of the Golden Rule of neighbourly love, saying to "treat others as you want yourself to be treated". For Raunio, the Golden Rule is not merely a horizontal rule between humans but also a rule in which Christians imitate the self-giving of Christ. While Holm and Raunio have found much textual support for their claims, they are also close to the path of synergism, a position which gives too much credit for human powers of reciprocal cooperation between God and humans.

In German Reformation studies, Berndt Hamm and Gury Schneider-Ludorff have investigated the concrete practices of gift-giving in neighbourly love. In her study of the endowments made to the church before and after the Reformation, Schneider-Ludorff comes to fascinating conclusions. On the one hand, her findings show that Protestants continued to donate their properties to the church in a manner which was similar to the Pre-Reformation practices. This is very interesting because Luther and other Reformers criticized such endowments for confusing the gift mode of salvation and the economic mode of worldly life.

On the other hand, Schneider-Ludorff finds out that the motivations expressed in the context of charity and endowments were different after the Reformation. After the Reformation, Protestants were careful to say that they do charity and make endowments just out of gratitude, not to achieve salvation. While the practices of charity and endowments to the church continued in an externally similar fashion after the Reformation, the explicit motivations were different. An awareness of the gift mode was explicit when people were dealing with the church.

These historical findings make an interesting case for anthropology. A skeptical anthropologist would perhaps say that the explicit motivations in letters of endowment can be regarded as mere by-products or as wishful thinking. If people donated their properties to the church in the same way before and after the Reformation, maybe their deepest motives were much more similar than what can be read from their pious texts.

Berndt Hamm, however, comes to different conclusions. In his recent progammatic study he claims that the discovery of the so-called "pure gift" in the Reformation was nothing less than a revolution in the entire history of religions. For Hamm, the late medieval religious practices continued what he calls the archaic logic of gift-giving as described in the classical work of Marcel Mauss. This archaic logic demanded reciprocity and worked as a mixed economy of the gift mode and the sales mode. Luther's message "grace alone" broke down this archaic logic, replacing it with the early modern idea of pure gift which does not demand any reciprocity. For this reason, we may say with Schneider-Ludorff that the different explicit motivations of charity were real results of this Copernican turn from Maussian anthropological reciprocity to the Lutheran and modern idea of a pure gift. 
We see that different scholars of the Reformation employ cultural anthropology to achieve different kinds of results with regard to neighbourly love. Bo Holm claims that Luther himself manifests traces of anthropological reciprocity. Berndt Hamm, on the other hand, finds that this archaic logic of reciprocity was the background against which Luther finds his revolutionary new idea of pure gift. Hamm's above-mentioned vision of the abundant grace as the maximal expression of non-monetary salvation supports his idea of the religious revolution that takes place in the new understanding of gift-giving discovered in the Reformation.

The difference between Holm and Hamm may not, however, be so great as it looks on the first sight. They both underline the continuities between medieval and early modern practices of charity and neighbourly love. In this manner, Luther's theology of gift and giving is strongly connected to anthropological theories in current scholarship. With regard to this connection the scholars are in agreement, although they interpret the outcome of this connection differently.

\section{The Lord's Supper}

Wolfgang Simon (2003) makes a provocative claim regarding Luther's eucharistic theology. Luther did not only criticize the Catholic Mass because of sacrifice, but Luther's own theology also contains an idea of sacrifice in the Lord's Supper. How can this claim be grounded? Simon builds his analysis of the Lord's Supper on the different conceptual dimensions of God's giving. Like many anthropologists and linguists, Simon claims that the verb "to give" sometimes contains four arguments: in addition to the giver, the gift and the recipient, there is the so-called beneficiary who benefits from the act of giving. Often the recipient is identical with the beneficiary. However, there are specific acts of giving in which the beneficiary differs from the recipient. Sacrifices are prominent examples of this kind. If a farmer sacrifices a sheep to God for the sake of his family, God is the recipient of the gift, sheep, and the family alllegedly benefits from this sacrificial act.

Roman Catholic theology of the Mass employs this four-place relation of sacrifice, discussing extensively the different roles of recipients and beneficiaries. Many Catholic practices of Luther's times require the separation between recipients and beneficiaries. For instance, in the private mass only the priest receives the bread, as there is no congregation present. But if the mass is considered to be a sacrifice, one can nevertheless argue that this private mass can benefit other people who are not present in the church, in the same way like the offering of the sheep can benefit the farmer's family. The same goes for requiem, the mass for the dead. While the dead are not present in the church, they may benefit from the mass, without receiving the sacrament. 
Luther's one main theological issue was to keep the recipients identical with the beneficiaries. In order to benefit from the eucharistic service, you need to be present and receive the cup and the bread. The congregation present in the church is both the recipient and the beneficiary of the sacrament. In addition to this well-known feature of Lutheran theology, there are two modes in which the congregation or the individual Christian performs a kind of sacrifice. The first of these is the sacrifice of thanksgiving. In giving thanks to God, the congregation enters a reciprocal relationship to God who is the host and the giver of the sacrament. This significance of thanksgiving is recognized by Lutherans in general and does not contain anything particularly new.

In addition to thanksgiving, the recipients of the Eucharist perform another kind of sacrifice in the Mass. Simon's study focuses on this evidence. Luther sometimes speaks of the believers as offering themselves as a living sacrifice. In some sense, this may mean the ordinary love and service of your neighbor. However, Luther sometimes seems to assume that this act is, like the act of thanksgiving, directed to God. In this manner, Christians offer something of themselves, like their own comfort, to God, so that their suffering is a sort of sacrifice. This is an interesting but also very complicated reading of Luther, and it has evoked some discussion around Simon's study. Luther clearly uses Augustine's (De trinitate 4, 3, 19) fourfold scheme of giver, gift, recipient and beneficiary in his eucharistic theology. While he fills the places of this scheme with new placeholders, the traditional fourfold scheme of giving and the gift still remains the basic structure of his eucharistic theology.

Simon's study offers some new insights concerning the sacramental theology of the socalled "gift mode". Both baptism and the Lord's Supper are God's gifts. They are also free and unconditional gifts in the sense that they cannot be understood in terms of "sales mode". No human merits or achievements are needed in order to encounter God in the sacraments. At the same time, baptism and the Lord's Supper also resemble what I labeled the ceremonial gifts in my threefold division of different anthropological gifts above. Unlike rain or sunlight, the sacramental gifts are not automatically poured over everybody. God gives them in a targeted manner, in personal encounter with a human being. Like the ceremonial gifts, the sacramental gifts constitute an initiation into a new community. Official Roman Catholic Catechism calls baptism and the Eucharist the "sacraments of initiation".

Like the ceremonial gifts of anthropology, the sacramental gifts establish some kind of reciprocity, although one should be very careful in defining this reciprocity. In order to receive baptism, the person should be alive; inanimate objects cannot receive baptism. Moreover, baptism should be reciprocated by personal faith. Anthropologists emphasize that ceremonial gifts should be reciprocated with proper delay. If I buy you a present today, you should not buy me one already tomorrow, but only after proper time has passed. Otherwise your gift looks like a payment of mine. Baptismal gift is often reciprocated in this manner. The infant is baptized now; his or her response follows after maturation and education. The 
"gift mode" presupposes that the response should be in some sense delayed and voluntary, so that it does not look like a payment to God. At the same time, this gift exchange nevertheless proceeds in some ceremonial fashion, observing fixed norms of politeness and symbolic representations. The ceremony of confirmation is in this sense a proper response to the baptismal gift.

The Lord's Supper is a particularly rich and many-sided gift of God, which may contain aspects of all three sub-types of gift. (1) As the self-giving of Christ for our sake this gift is free and unconditional. The Eucharist manifests God's love as agape in a truly free and absolute manner. It is a rule of the gift mode in which no payments are expected or accepted. (2) At the same time, the Lord's Supper entails ceremonial dimensions. It is performed as a fixed part of worship liturgy, and this liturgy consists of many reciprocal prayers and readings, which together constitute the ceremony at hand. Reciprocity is present at least in the form of giving thanks to God, and maybe also in the form of our self-giving to God. An extremely important aspect of ceremonial gifts is the creation of communion bonds among the participants of gift exchange. This is a theologically prominent aspect of the communion table. The Lord's Supper creates and sustains the communion of believers. In this sense it resembles the ceremonial gifts discussed in anthropology.

(3) Thirdly, the Eucharist also expresses the mode of "keeping-while-giving". As the Lord's Supper constitutes the community of believers, it also creates the family of faith in which the deposit of true doctrine is being carried forward. The mode of "keeping-while-giving" is particularly visible in the Roman Catholic and Eastern Orthodox practice in which the communion table is not open to outsiders. In Lutheranism, different practices can be observed. While some claim that an open communion expresses the "gift mode" better than a the closed communion of church members, others think that a clear belonging to the family of communion needs to be required. Both views can be theologically defended. From the perspective of anthropology, the closed communion of "keeping-while-giving" can express a particulary precious gift.

The aim of these three points is not to reduce the sacraments to an anthropological theory. While various theories of the gift can elucidate important aspects of baptism and the Lord's Supper, the sacraments also contain other important truths and mysteries. Such truths need to be defined with the help of the Scripture. When Luther scholars present elaborate theories of theological gifts, sacramental theology is one area in which their claims can be illustrated and tested. In sum, the sacraments express some kind of ceremonial reciprocity. At the same time they also strongly express the monergy of God who gives personally targeted gifts in a fully unconditional manner.

\section{Justification}


The notion of the gift has traditionally been discussed in the context of the Lutheran doctrine of justification. Both Luther and Melanchthon speak of Jesus Christ as God's favor and God's gift in the justification of the sinner. The two notions of favor and gift have provoked traditional controversies. One received opinion emphasizes forensic justification and considers that the God's favor is the central feature in justification. The favorable attitude of God enables the forgiveness of sins because of the atoning work of Christ. In this view, the gift of God is called sanctification rather than justification. The justified believer may receive some fruits of faith or the Holy Spirit, and they can be called special gifts or charisms. These gifts are not, however, part of justification but they belong to sanctifaction.

Another received opinion, defended today by many ecumenically-minded scholars, considers that justification is both forensic and effective, consisting of God's favor (forensic side) and God's gift (effective side). When Christ becomes present in the faith of the Christian, he is both God's favor and God's gift. A strong adherent of this opinion even considers that neither of these aspects has priority over the other. Being of equal importance, they always accompany each other. This view resembles the Catholic doctrine of salvation. It has been fruitfully employed in Lutheran - Roman Catholic ecumenical dialogue. The defenders of the first position have, however, often remained skeptical with regard to this option. They consider that only the forensic justification can preserve the certainty of faith and the monergy of God's saving act of justification. As the effective side remains imperfect or partial, Christians can only put their trust to God own favor in Christ, not to anything that dwells in us.

Recent discussions on the precise nature of giving and gifts can shed some light upon this traditional difference of opinions, making visible an intermediate position. Already the ancient philosophers claim that the gift can only be called a gift if we know the intention of its giver. If I find your book lying on my table, I might think that you have given it to me as a gift. However, I may also be mistaken. Maybe you just forgot the book there and had no intention to give it to me as a gift. In order to know whether it is a gift, I need to know your intention. Similarly, my receiving money from you may be a salary, or a bribe, or, sometimes, also a gift, always depending on your intention. This means, in other words, that the gift always needs the favorable attitude in order to be a gift.

The other way round, however, the matter looks different. It is possible to have a favorable intention when no gift is given. I may say, for instance, that I love you very much but right now I cannot afford to give you anything. Or when we say, for instance, goodbye, or farewell, we want to convey our good attitude in a situation in which we actually do not give any material gift item but merely the good wish.

Granted, the matter is complex, since in many cases the good wish at least socially needs to be accompanied with the gift itself. We do not say to our children in Christmas time: I only 
give you my good will, but not the Christmas present. When we go to a wedding, we normally do not say: I congratulate you, but I did not bring any wedding present. Similarly, it would be strange if a strong adherent of forensic justification says: God justifies us in his mind, but God does not make us any better and God does not want to transform us in any way. We may debate whether such transformation belongs to justification or sanctification, but it would be odd to have a doctrine of salvation in which nothing really changes.

To draw theological conclusions from these observations: justification needs to be both forensic and effective, because otherwise the gift would be left on the wayside. In this sense I side with the adherents of the second opinion. However, I also think that forensic justification has some priority over effective justification, since the gift needs favor, but favor does not necessarily or always need any gift. This priority is not a priority of chronological sequence, but it is a logical or semantic priority of favor over the gift. When Christ dwells in the believer, he is simultaneously God's favor and gift. His being the gift is nevertheless defined by his being favor, and not vice versa.

However, the theological matter remains complex, and its truth is not decided upon the philosophical meaning of words as such. Instead, we should look closely at the Biblical texts and early Lutheran confessions, interpreting their doctrine of justification from this angle. The remarks made above give some conceptual signposts, showing the relevance of gift discourse in matters regarding the justification of the impious.

\section{New Biblical Challenges}

The scholarship and discussions presented above more or less assume the Latin and German vocabulary of giving and the gift. Its Greco-Roman background is found, on the one hand, in the Greek verb didomi and other verbs and nouns in which this verb can be heard. On the other hand, the Latin term beneficium and its vernacular equivalents have prompted the classical Western philosophical discussions.

This picture, complex enough in itself, gets much more complicated if we assume that the Greek word charis, "grace", can also mean "the gift". Lutheran discussions have to some extent avoided this assumption, thinking that the Latin terms favor and gratia already cover the Biblical terminology of grace. Recently, John Barclay has argued in great detail that the apostle Paul employs charis in the sense of "the gift". Moreover, Barclay claims that we can only understand Paul adequately if we pay very serious attention to the anthropological gift theories of Mauss and others as well as to the philosophical views of Seneca and Philo.

Barclay thus introduces anthropological awareness to New Testament studies in a manner which resembles Bo Holm's and Berndt Hamm's attempts in Luther studies. Like Hamm, Barclay considers that the notion of the "pure gift" is a modern invention. He also joins 
Hamm in thinking that Luther himself has contributed significantly to the emergence of this notion in modernity.

The monumental work of Barclay is too big to be discussed briefly. In any case, it makes the anthropological gift exchange an even hotter topic in today's historical and systematic theology. Instead of pure gift, Barclay likes to speak about six different perfections of grace, each of which highlights a different aspect of purity or perfection. For Barclay, Luther's theology exemplifies in particular the so-called incongruity of grace. This perfection means that grace is given without paying any attention to the worth of the recipient.

In addition, Luther's theology manifests for Barclay the so-called non-circular perfection of grace. This means that grace is given without any expectation of return. Non-circularity does not mean that neighbourly love and works of charity are neglected. They are done purely for the sake of others, without any instrumental reasons or other expectations. It is yet too early to say whether Barclay's new vocabulary of perfections can be fruitfully employed in Luther studies. On the first look, it is very promising and may provide differentiations which are needed not only in Pauline studies but also in Luther research.

The big challenge is not, however, this terminology but Barclay's claim whether the entire Pauline theology of grace can be better understood with the help of anthropological gift exchange. If this claim is affirmed, new scholarship on Luther, as well as on Augustine and Thomas Aquinas, is needed to grasp this reception-historical perspective of Christian anthropology.

\section{Bibliography}

Barclay, John, Paul and the Gift, Grand Rapids: Eerdmans 2015.

Bayer, Oswald, Martin Luthers Theologie, Tübingen: Mohr Siebeck 2003. Godbout, Jacques, The World of the Gift, Montreal: McGill-Queens 1998. Hamm, Berndt, "Martin Luther's Revolutionary Theology of Pure Gift without Reciprocation", in: Lutheran Quarterly 29, 2015, pp. 125-161. Hamm, Berndt, Ablass und Reformation, Tübingen: Mohr Siebeck 2016. "Hand of God", in: Religion Past and Present, Brill online edition 2007. Henaff, Marcel, The Price of Truth, Stanford: Stanford University Press 2010. Holm, Bo Kristian, Gabe und Geben bei Luther, Berlin: de Gruyter 2006. Mauss, Marcel, The Gift, London: Routledge 1990 (orig. 1925).

Newman, John, Give: A Cognitive Linguistic Study, Berlin: de Gruyter 1996.

Raunio, Antti, Summe des christlichen Lebens, Mainz: Zabern 2001. Saarinen, Risto, God and the Gift, Collegeville: Liturgical Press 2005. Saarinen, Risto, "Luther the Urban Legend", in The Global Luther, ed. C. Helmer, Minneapolis: Fortress 2009. 
Schneider-Ludorff, Gury, Der neue Sinn der Gabe. Stiftungen im Luthertum des 16. und 17. Jahrhunderts, in: Jahrbuch Biblische Theologie 27, 2012, 277-291.

Seils, Martin, "Die Sache Luthers", in Lutherjahrbuch 52, 1985, 64-80.

Seils, Martin, „Gabe und Geschenk“, in Denkraum Katechismus, ed. J. von Lüpke \& E. Thaidigsmann, Tübingen: Mohr Siebeck 2009, 87-103.

Simon, Wolfgang, Luthers Messopfertheologie, Tübingen: Mohr Siebeck 2003.

Taylor, Charles, Sources of the Self, Cambridge: CUP 2002.

Weiner, Annette, Inalienable Possessions, Berkeley: University of California Press 1992. Zemon Davis, Natalie, The Gift in Sixteenth-Century France, Oxford: OUP 2002. 